\author{
Todd Donovan \\ Western Washington University \\ todd.donovan@wwu.edu (corresponding author) \\ Jeffrey Karp \\ University of Exeter \\ jeffrey.a.karp@gmail.com
}

Electoral rules, corruption, inequality and evaluations of democracy

\begin{abstract}
Features of electoral systems have been found to have positive effects on evaluations of democracy. We propose that there are larger social forces that must be accounted for in such analyses. Using European Social Survey measures of democratic expectations and the 'satisfaction with democracy,' item, we test for effects of electoral rules on perceptions of democracy. We find that multipartyism / proportionality and preferential ballot structure appear to correspond with positive evaluations of elections, parties, and with greater satisfaction with how democracy is functioning. However, these relationships dissipate when corruption and income inequality are accounted for. This suggests substantial limits to the capacity of electoral reforms to enhance democratic legitimacy. It also suggests that studies of mass perceptions of democratic performance may overestimate effects of electoral rules if country-level corruption and income inequality are not accounted for.
\end{abstract}

Keywords: public opinion, democracy, corruption, inequality

Dec. 2016. Forthcoming, European Journal of Political Reasearch 


\section{Electoral rules, corruption, inequality and evaluations of democracy}

\section{Introduction}

In the comparative study of democracy, scholars give particular attention to the role electoral institutions play in structuring diffuse support for a democratic regime (Sartori 1997; Lijphart 1994; 1999). Research in this area is motivate by the assumption that dissatisfaction with the functioning of representative democracy can pose a threat to the legitimacy of democratic systems (Lipset 1960; Easton 1965; Powell 1982). It seems fitting then, that a literature of 'electoral engineering' is on hand for reference when new democracies emerge and existing ones consider electoral reform (Lijphart \& Grofman 1984; Horowitz 1991; Sartori 1997; Reilly 2001; Reynolds 2002; Norris 2004). Reformers expect much could be gained when new electoral institutions are designed. For example, studies suggest that proportional electoral systems (e.g. Anderson \& Guillory 1997; Lijphart 1999; Klingemann 1999; Powell 2000; Karp \& Banducci 2008; but see Aarts \& Thomassen 2008) and candidate-centered voting (Farrell \& McAllister 2006) may be associated with people viewing democratic performance more positively and with people having greater engagement with democracy.

We propose there are limits to the extent that such electoral rules can affect how people evaluate the performance of elections and democracy. Others have recognized that factors separate from electoral institutions also shape assessments of democratic performance, most notably evaluations of economic conditions (Anderson \& Guillory 1997; Thomassen \& van der Kolk 2009), and the rule of law (Wagner et al. 2009). This paper demonstrates that the capacity for electoral institutions to affect attitudes about 
representative democracy may be more limited than previously appreciated. We show that variation in electoral rules matter less to evaluations of elections and democracy when the effects of broader social forces are considered.

This paper makes several contributions to our understanding of attitudes about democracy. First, we employ new measures of how people evaluate democratic performance, measures that capture attitudes of what people expect from elections and party systems. Second, we show that these new measures correlate with, but are distinct from, satisfaction with democracy. Third, we develop a theoretical basis for including income inequality and corruption as important social forces that affect how people view electoral democracy. Fourth, we replicate previous models that showed proportional representation and preferential electoral systems associated with satisfaction with democracy, and we find these electoral rules appear to predict positive assessments of elections and party systems. Fifth, and perhaps most important, we demonstrate that all of these models are substantially underspecified if they do not account for corruption and inequality in a country. Electoral system features largely have null effects on evaluations of democracy when corruption and income inequality are accounted for.

\section{Attitudes about democratic performance}

Scholars since Easton (1965) have differentiated between specific and diffuse support, with the former reflecting attitudes about the government of the day and its outputs, while the latter reflects broader attachments to the political system. Research has determined that these two aspects of political support are well correlated, and that there are additional dimensions to attitudes about system support and democratic 
legitimacy (Harmel \& Robertson 1986; Kasse 1988; Weatherford 1992; Norris 1999; Rose \& Mishler 2002). Many studies (e.g. Weil 1989; Anderson \& Guillory 1997; Kuechler 1991; Clarke \& Kornberg 1992; Klingemann 1999; Fuchs 1999; Karp et al. 2003; Leiter \& Clark 2015) have employed a widely used measure of satisfaction with democracy as an indicator of system support. Satisfaction with democracy is meant to capture an evaluative, non-affective perspective on how democracy is functioning, rather than just reflecting attitudes about "particular individuals or parties holding power" (Lockerbie 1993: 282).

Several scholars have noted that there is a lack of clarity as to what the satisfaction item actually measures. Dalton (1999) notes the item cues respondents to consider evaluations of government performance, and thus may represent specific rather than diffuse support. Norris (1999) contends the satisfaction item is problematic because the question means different things to different people within a nation, and different things across nations (cf. Canache et al. 2001).

We are in no hurry to dispose of the satisfaction with democracy item, but concur that it may be a somewhat nebulous measure of how much people support democracy as a system of government. Our concern is with how well people think democracy is functioning in their country, and the item is a decent reflection of how people view a democratic regime working in practice (Linde \& Ekman 2003). We measure perceptions of democratic performance with the satisfaction question, but we also measure evaluations of democracy with questions asking about the fairness of elections and the choices offered by the party system. We suggest these items measure evaluations of very basic (and crucial) procedural aspects of electoral democracy. 
A functioning democracy requires that people are allowed to choose between political rivals (parties) in free and fair elections that are conducted with some measure of integrity (Dahl 1956; Norris 2014). We construct two measures of evaluations of democratic performance that capture both an individual's general expectation about democracy and their perception of how democracy is performing in their country. One item is based on evaluations of whether elections are free and fair, the other on evaluations of the quality of choices offered by political parties. We use questions from Wave 6 of the European Social Survey (ESS) that asked people what they expected from democracy as a general concept, and what they thought democracy actually delivered in their own country. People were asked to rate on a 0-10 scale how important it was for democracy in general that elections were free and fair. After that, they were asked, 'considering things in your country, how much do you think elections are free and fair?' Another item asked them to rate how important it was to democracy that political parties offer clear alternatives. After that, they were asked, 'and in your country, how much do you think that parties present clear alternatives?' We subtract a person's score on the second question about performance from their score on the first question about expectations in order to measure how much people think democracy in practice is meeting or failing to meet their personal expectations of democracy. In effect, this measures their level of dissatisfaction, or disappointment (Seyd 2015) with these two features of electoral democracy (see Appendix for full details).

By measuring the gap between what someone expects from democracy and how they perceive it to be working, we account for survey responses being biased due to people having different expectations about how important parties and elections are to 
democracy. Our 'expectations gap' items capture attitudes about democratic performance that are related to, but are richer and more specific, than a question asking about satisfaction with democracy.

\section{Corruption, inequality and evaluations of democracy}

Evaluations of democracy - views of the legitimacy of elections and satisfaction with democracy - are driven by individual-level and country-level traits. At the individual-level, education, economic evaluations, interest in politics, and being aligned with a party in government have been found to condition how people view democratic performance. Country-level factors have also been identified as conditioning views of democratic performance. Having a consensual (proportional representation / multiparty) rather than majoritarian political system (e.g. Anderson \& Guillory 1997), preferential (candidate centered) voting (Farrell \& McAlister 2006), longer experience with democracy, and less corruption (Pharr \& Putnam 2000; Anderson \& Tverdova 2003; Wagner et al. 2009; Clausen et al. 2011; Ferrin 2016) have been held to be associated with more positive assessments of democracy.

We are interested in systemic, country-level forces that affect how people evaluate electoral democracy in their country. Evaluations may reflect a running tally of assessments of how a political system is functioning, but what affects this tally? By managing conflict more effectively than majoritarian systems, and by enhancing representation of political minorities, proportional / multiparty systems might cause individuals in those nations to view their elections and party system more positively, and be more satisfied with democracy (Lijphart 1999; Anderson \& Guillory 1997). Similarly, 
by giving people greater flexibility to express their political preferences, and by encouraging accommodation among political rivals, variants of preferential voting (as opposed to closed-list, categorical voting) may likewise cause people to have more positive assessments of elections, parties, and democracy (Reilly 2001; Farrell \& McAllister 2006).

The electoral system, as a causal force, could affect positive effects on perceptions of electoral democracy over time by conditioning the voting experience and / or by broadening the range of parties in government and the legislature. But there are larger social forces that we also expect people to consider, perhaps more immediately, when they are asked about how elections and democracy are performing in their country. Reflections about of democratic performance, implicitly or explicitly, likely trigger considerations of procedural fairness. Democracy, after all, is a process of allocating resources and managing conflict. Given the role of considerations of procedural and distributional fairness in public attitudes about democracy (Tyler 1990; Hibbing \& Theiss-Morse 2001), questions that ask for assessments of democratic performance are likely to trigger considerations of country-level conditions such as corruption and inequality, as these forces are intricately linked to conceptions of fairness.

Corruption is the subversion of fair process, where the rule of law is not applied equally (or at all); and the corrosive effects of corruption are well documented (e.g. RoseAckerman 1978; Triesman 2000). Corruption has been shown to erode political trust, and it is associated with pessimism about democratic performance (Anderson \& Tverdova 2003; Wagner et al. 2009). Rose \& Mishler (2002) propose that the rule of law is the single most important determinant of support for democratic or non-democratic 
regimes, yet empirical analysis of the effects of electoral rules on attitudes about democracy rarely, if ever, include corruption as a country-level factor. This means we do not really know the relative extent that electoral institutions or broader social conditions contribute to evaluations of how elections and democracy are working.

Income inequality is a second county-level condition that may affect evaluations of democracy in a similar manner. Some models of attitudes about democracy have included measures of country-level economic factors ${ }^{1}$ (Thomassen \& van der Kolk 2009; Anderson \& Tverdova 2003), but a rare study that considered the aggregate-level relationship between inequality and county-level satisfaction with democracy produced a "puzzling" result, with a positive relationship between inequality and satisfaction (Wagner et al. 2009:39). ${ }^{2}$

We suggest inequality is a key socioeconomic phenomena that people consider when they evaluate the performance of elections and democracy, particularly if their evaluations are based on perceptions of distributional and procedural fairness. Income inequality has systemic consequences for democratic processes as it causes a country's system of political representation to be distorted, given that political and economic power are so inter-related. Where inequality is greater, it is less likely that the political interests of the many are represented and more likely that the interests of a wealthy elite are given disproportionate influence (Bartles 2008; Hacker \& Pierson 2010). Solt (2008)

\footnotetext{
${ }^{1}$ Anderson \& Gillory (1997), Karp et al. (2003), Karp \& Banducci (2008); Aarts \& Thomassen (2008) do not include measures of country-level economic conditions when modeling engagement with and attitudes about democracy. Farrell \& McAllister (2006) found no relationship between GDP and perceptions of parties, or perceptions that elections were fair, but found it associated with greater satisfaction with democracy. These studies tend to report rather low $\left(\mathrm{R}^{2} .00\right.$ to .10$)$ model fit.

${ }^{2}$ These authors suggest their result may be due to an inappropriate measure of inequality.
} 
documents that higher levels of income inequality "powerfully depress political interest, the frequency of political discussion, and participation in elections among all but the most affluent citizens." Dotti Sani \& Magistro (2016) also note the link between social and political inequalities, and suggest that increasing inequality in economic conditions could fuel political cynicism in Europe (cf. Dalton 2005). As for the widespread salience of inequality as an issue, majorities in all of 44 nations surveyed in 2014 agreed that the gap between the rich and poor was a big problem facing their country. This sentiment was particularly pronounced in European countries hit hardest by the Great Recession. ${ }^{3}$

In short, when compared to the country-level effects that electoral institutions might have, we expect that people are much more likely be affected by country-level corruption and inequality when they are asked about how elections and democracy are working in their country.

\section{Individual-level hypotheses}

We estimate multi-level models of evaluations of elections and democracy in Europe. At the individual level, the politically invested (electoral winners) are expected to be less likely to see parties and elections as falling short, and should be more satisfied with democracy (Anderson \& Guillory 1997; Anderson et al. 2005). Respondents were coded as electoral winners if they had supported the party gaining the most seats in the most recent election. ${ }^{4}$ Conversely, people who thought their finances were doing poorly are expected to be more dissatisfied with the process of democracy. Education and

\footnotetext{
${ }^{3}$ Pew Spring 2014 Global Attitudes survey.

${ }^{4}$ Alternate codings of winners that included all people who support a party that was in government (Singh et al. 2012) did not alter our substantive results. We could not cleanly identify non-optimal winners (Singh 2013).
} 
political interest are also accounted for, and the literature gives us mixed expectations here. Some have found no consistent relationship between education and satisfaction with democracy (Anderson and Guillory 1997; Farrell \& McAllister 2006). Conversely, cognitively sophisticated respondents may be more critical of traditional democratic political arrangements (Fuchs \& Klingemann 1995; Norris 1999; Karp et al. 2003; Dalton 2007). Gender, age, and voting status (non voter) are also included in our models as controls (see Appendix for variable coding).

\section{Country-level hypotheses}

We are primarily interested in the rival effects of electoral system features, compared to the effects of corruption and inequality. Existing literature suggests that people who live in countries with proportional representation and/or multiparty systems will be less likely to see elections and parties as failing to live up to their expectations about democracy, and should be more satisfied with democracy. Likewise, previous research leads us to expect that the more candidate-centered (preferential) a nation's ballot structure is, the less dissatisfied people will be.

We stated above that there are strong reasons to expect that where there is more public corruption, citizens are more likely to be disappointed with elections and parties, and to be less satisfied with democracy how democracy is working. Likewise, we also expect that where income inequality is greater, perceptions of fair process will be degraded such that people will be less inclined to believe that elections and parties are performing as they should, and they will feel satisfied with how democracy is working. Our primary hypothesis about the rival effects of electoral institutions and social 
conditions is this: As major social forces that condition how people perceive the fairness of democratic processes, income inequality and political corruption will have larger substantive effects on evaluations of elections and democracy than electoral institutions.

\section{Data and measures}

Countries studied under the European Social Survey (ESS) provide an excellent setting for testing these hypotheses given the variation in electoral system features, political, economic and social conditions across the cases. Our measures of opinions about elections, parties, and democracy are drawn from Wave 6 of the ESS; Wave 6 was conducted in 29 countries between 2012 and 2013. Twenty-eight of these cases are used in the main analysis, ${ }^{5}$ with the $21 \mathrm{EU}$ countries covered in Wave 6 used for robustness tests. ESS respondents were asked to rate "how satisfied are you with the way democracy works in [country]" on a 0 - 10 scale, where 0 represented extremely dissatisfied and 10 represented extremely satisfied. We also use ESS items described above to measure the gap between expectations and perceptions of elections being free and fair, and to measure the gap between expectations and perceptions that a country's party system offered clear choices. Both of these also range from 0 - 10 (see Appendix for question wording), ${ }^{6}$ with

\footnotetext{
${ }^{5}$ Kosovo was excluded in the initial tests due to lack of data on income inequality.

${ }^{6}$ People who reported they thought free elections [party choices] were not at all important, but that elections [parties] were doing very well, had negative values. We consider this to reflect indifference or random measurement error and recode negative scores at zero. Results we report are substantively the same regardless of whether the small number of respondents with negative values were included, or scores were translated to absolute values, set to zero, or omitted. Results of additional models using expectations as a predictor of perceptions discussed in this paper (and in the online Appendix) make us confident that this coding did not bias our results.
} 
higher scores reflecting that a respondent expected more from fair elections and parties than she perceived to be the case in her country.

As for our country-level measures, multipartyism is measured with Gallagher's indicator of the effective number of legislative parties (Gallagher 2014; Gallagher \& Mitchel 2008), and proportionality is measured with Gallagher's $(1991,2014)$ least squares measure of the disproportionality. We measure the preferential / candidatecentered nature of a country's balloting with Farrell \& McAllister's (2006) application of a Shugart (2001) and Carey \& Shugart (1995) indicator of how much a country's voting system was candidate-centered (versus closed party list). Country-level corruption is measure with Transparency International's (TI) index, as reported at the time the ESS was conducted. The TI measure is inverted here so high scores reflect greater corruption. On this measure, the most corrupt countries among our cases were Ukraine (75), Russia (72), Bulgaria (59) and Italy (56). The least corrupt were Denmark (9), Finland and Sweden (11), and Norway (14).

For income inequality, part of the analysis uses a measure of change in a nation's gini index, using data reported by the US Central Intelligence Agency. Change was calculated by subtracting the gini measure reported most recently prior to when the ESS was conducted in the country from the measure reported previous to that. The time intervals between measures are not constant, but generally span 11 years (1998-2009). The idea here is that increasing inequality would have a more tangible effect on assessments of democratic performance than static inequality. The highest values of change were recorded in Albania (7.8\%) and Bulgaria (19.3\%), Italy (4.6\%), and Portugal (2.9); while the lowest were in Estonia (-5.0\%), Switzerland (-4.4\%) and 
Germany (-3.0\%). We also conducted robustness tests (discussed below) using different measures of inequality.

In addition, we have a static measure of income inequality from the European Union circa 2010 as reported by the EU/ Eurostat for $20 \mathrm{EU}$ countries that overlap with Wave 6 of the ESS for robustness replications. For these cases, the highest income inequality was recorded in Portugal (gini $=34.2)$, Spain (32.6), Lithuania (32.4) and Great Britain (32.4); the lowest was Sweden (23.8) and Slovenia (23.8), Netherlands (24.8), Switzerland (25.1) and Slovakia (25.4). A World Bank measure of growth in Gross Domestic Product (for the year the survey was conducted) is also included as an additional control for broader macroeconomic conditions. We expect economic growth may correspond with more positive views of elections and democracy. ${ }^{7}$

Figure 1 about here

Figure 1 displays country-level variation in our measures of disappointment with elections and parties, and also plots satisfaction with democracy. The first values represents the average gap between expectations and perceptions of elections in a nation, the second illustrates this gap regarding political parties. The third values plot the average rating on the satisfaction with democracy measure. It is apparent that satisfaction with democracy tends to be lower where the electoral expectations gaps are larger. Countries are arrayed by the largest (Ukraine) to smallest (Finland) gaps in expectations of parties and elections. Gaps were highest in less established democracies such as Ukraine (5.72 for elections, 4.61 for parties), Bulgaria (5.42, and 4.69), and Albania; and

\footnotetext{
${ }^{7}$ Absolute levels of GDP are highly correlated with our corruption measure, so the two cannot be included together in the same models.
} 
lowest in Finland ( 0.43 with elections, 1.29 with parties), Sweden (0.57 and 1.62), the Netherlands (0.92 and 1.46), and Norway (0.61 and 1.81).

The figure illustrates how the measures of these democratic expectations are related to, but somewhat distinct from the satisfaction with democracy question. Note that country-level average scores on satisfaction with democracy are very similar for the Czech Republic (4.97), Lithuania (4.94) and Poland (4.90). At this level of satisfaction with democracy, Czechs and Poles would appear to be fairly sanguine about their elections. Yet the gap between expectations and perceptions of elections is twice as much in Lithuania despite the fact it had a similar level of satisfaction with democracy. The satisfaction with democracy measure is modestly correlated with our expectationsbased measure about parties offering clear choices $(\mathrm{r}=-.29)$, and with our measure about elections being free and fair $(\mathrm{r}=-.45)$, and these two expectations items are correlated at .44. These electoral expectations-based evaluations of democracy thus expand upon the standard satisfaction with democracy measure.

Testing hypotheses across multiple items measuring evaluations of democracy allows us to assess how the satisfaction with democracy item compares to items that explicitly evaluate the performance of electoral democracy. Furthermore, we want to know if previous findings about the relationships between electoral system features and satisfaction with democracy are robust - particularly when compared to items asking about electoral democracy. Most important, this provides multiple tests of whether reported links between electoral rules and evaluations of democracy remain present after we have accounted for corruption and inequality, two forces that have been understudied in this context thus far. 


\section{Method}

Tests of our hypotheses - particularly our primary hypothesis about the relative impact of country-level factors - require the use of multi-level (mixed) models. Standard OLS estimates of large sample survey responses collected across a relatively small number of countries would likely bias estimates of standard errors such that the likelihood of Type I errors would increase (Steenbergen \& Jones 2002). Multi-level models account for this, while also allowing us to identify an intra-class correlation value that estimates variance explained by country-level factors versus individual-level variables.

Our three measures of attitudes about democratic performance are estimated with random intercept models at the country-level. In the estimations reported below, we begin with a baseline random effects model (Model 1) that determines the proportion of variance attributed to country-level factors. Model 2 builds on this by adding individuallevel covariates and two country-level electoral system covariates. We do this in order to see if we can replicate previous (OLS) models that found proportional representation and preferential voting associated with greater satisfaction with democracy. Model 3 adds corruption and income inequality. Our primary hypotheses about the rival effects of electoral rules versus social conditions can be tested by comparing results of Model 2 to Model 3.

\section{Results}

Table 1 displays multi-level estimates of our models of expectations-based evaluations of elections being free and fair. Higher values on the dependent variable here 
reflect that a respondent's democratic expectation about elections was not being met. The intra-class correlation (ICC) estimated from Model 1 indicates that country-level forces can explain a substantial $31 \%$ of variation in these attitudes.

Model 2 in Table 1 is estimates the effects of electoral rules on evaluations of democracy, while omitting the effects of corruption and inequality. It illustrates that respondents in countries with multipartyism and preferential voting (respectively) do appear to be significantly more likely to perceive that their country's elections met their expectations about being free and fair. And, consistent with previous studies on satisfaction with democracy, Model 2 in Table 1 demonstrates that electoral winners, those interested in politics, and people satisfied with their economic circumstances were more likely to find elections meeting their expectations about democracy.

Table 1, 2 and 3 about here

We find similar patterns when we use this standard model to estimate perceptions about political parties offering clear choices (Table 2, Model 2), and when we estimate satisfaction with democracy (Table 3, Model 2). The ICC in Table 2 indicates that $12 \%$ of variance in attitudes about whether parties offered meaningful alternatives was due to country-level factors. Table 3 demonstrates that $24 \%$ of variance in satisfaction with democracy is associated with country-level factors. Again, when our models omit social conditions we find results similar to the existing literature: there are significant independent relationships between multipartyism and preferential voting. Each factor appears to be associated with people being more likely to say that their perceptions of parties offering alternatives met their democratic expectations (Table 2, Model 2). We also find these same electoral rules to be associated with greater satisfaction with 
democracy (Table 3, Model 2). The largest substantive and most consistent relationships across the models at the individual-level are for electoral winners and economic evaluations. Gender and participation (voting) are insignificant across the models, with mixed results for education and interest.

Overall, the results demonstrate that our expectation-based measures of perceptions of electoral democracy (Table 1 and Table 2) behave similarly to the satisfaction with democracy item (Table 3). This suggests the satisfaction with democracy item likely taps some sentiments about electoral democracy. Results from Model 2 in tables 1, 2, and 3 also suggest that relationships between electoral arrangements demonstrated in previous studies of satisfaction with democracy hold true here when estimated with mixed-level models in these countries.

All of this may suggest a potentially robust relationship between electoral institutions and attitudes about elections and democracy. This is where many previous studies of the relationship between electoral systems features and perceptions of democracy have concluded: Electoral system attributes are seen as having substantive effects on how people evaluate the performance of democracy in their country. This, despite literature (e.g. Pharr \& Putnam 2000; Anderson \& Tverdova 2003; Wagner et al. 2009; Clausen et al. 2011) establishing that people in countries with higher levels of corruption have more negative attitudes about the performance of their political system. Do these relationships between electoral rules and attitudes persist when corruption and inequality are accounted for?

Results from Model 3 in tables 1, 2 and 3 (and other models in the Appendix) challenge the idea that electoral system features are robust forces affecting how people 
evaluate elections and democratic performance. Model 3 in Table 1 indicates that when we introduce country-level measures of corruption and income inequality, electoral features such as multipartyism and candidate-centered voting are no longer significant predictors of perceptions of elections being free and fair, and the model fit more than doubles. Corruption and inequality stand out as the main country-level forces associated with perceptions of electoral integrity. Model 3 in Table 2 likewise illustrates that when inequality and corruption are introduced into the estimation of perceptions of a country's party system, any potential effects of multipartyism and method of voting are, again, truncated and no longer significant. Meanwhile model fit increases and corruption and inequality are associated with greater disappointment with parties. Likewise, Table 3 demonstrates that corruption and inequality (at just p. $<.09$ two-tail) are associated with less satisfaction with democracy, and that when these are accounted for the relationship between multipartyism on satisfaction with democracy is cut by more than half, the association of candidate-centered voting with satisfaction with democracy dissipates, and model fit increases. Results for GDP growth are a bit mixed. Growth corresponded with significantly lower disappointment with choices offered by parties, and a positive (but not significant) relationship with satisfaction with democracy. However, growth corresponded with greater disappointment about elections being free and fair.

All of this is consistent with our proposition that higher levels of corruption and inequality are likely to affect considerations of a lack of procedural fairness and colour how a respondent views electoral democracy and democratic performance.

\section{Robustness tests}


Additional models (not reported here) used the Anderson \& Tverdova (2003) specification, where the relationship between corruption and evaluations of democracy was estimated as being conditioned by whether or not a respondent voted for a winning party. Consistent with their results, we find that corruption does not correspond with diminished evaluations of electoral democracy or satisfaction with democracy as much among people who supported winning parties. As with the models we report here, corruption and inequality continued to trump the relationship between electoral system features and attitudes. However, this multiplicative specification did not add to model fit.

We also conducted a series of tests (in the online Appendix) that confirm these substantive results are robust across several different estimations, when the analysis is limited to the European Union, when different measures of electoral system features are employed, and when alternate measures of income inequality are employed. One set of models estimated perceptions of elections and parties with expectations about these, respectively, as independent variables. In effect, rather than modeling the absolute distance between expectations and perceptions, we lagged our estimate of a person's perceptions about the performance of electoral democracy with their expectations.

We find the same substantive results reported here. When perceptions of the performance of elections, and of parties offering choices, are estimated without accounting for corruption and inequality, multipartyism and method of voting appear to correspond with perceptions that democracy is performing better - even with expectations accounted for as an independent variable. However, the coefficients for the electoral system features were no longer significant when corruption and inequality are included. 
Another set of robustness tests replaced the measure of multipartyism with Gallagher's least-squares measure of disproportionality. Once more, we find results similar to the existing literature: respondents in countries with greater disproportionality were less likely to say elections were free and fair, less likely to say parties offered clear alternatives, and were less satisfied with how democracy was working. However, the relationship between disproportionality and attitudes disappears, or in the case of satisfaction with democracy, is reduced in magnitude by nearly two-thirds, when we account for corruption and growing income inequality in a country.

Additional robustness estimated models only with respondents from the $21 \mathrm{EU}$ nations where Wave 6 of the ESS was conducted, and these models were estimated first with the measure of change in income inequality, and, separately, with alternate measure of income inequality reported by the European Union. ${ }^{8}$ We find the same pattern of substantive results as reported in the main body of this paper. Across the EU, people in countries with more parties in the legislature and in countries with candidate-centered voting systems initially appear less likely to have seen elections and parties as falling short of their expectations of democracy, and these country-level features of elections were both associated with greater satisfaction with democracy.

However, when corruption and income inequality are accounted for the apparent effects of these electoral rules is substantially altered - effectively driven to zero with relation to our measures of the performance of electoral democracy, and having a significantly smaller relation with satisfaction with democracy. Model fit also increases notably when social conditions are added. It is important to note that even in cases

\footnotetext{
${ }^{8}$ There was no data for Ireland on this measure.
} 
limited to the EU, income inequality (regardless of how it is measured) and corruption have demonstrable, adverse relationships with how people evaluate democratic performance - relationships that trump previously reported associations between electoral rules and assessments of democratic performance.

One noteworthy measurement issue here is that results were persistent across three different measures of evaluations of democratic performance - our expectationsbased measures of the performance of elections, and of the party system (respectively), and the satisfaction with democracy question. Since results are similar when the elections, parties, or satisfaction with democracy measures are used, this lends support to the idea that the satisfaction question is tapping attitudes about electoral process aspects of democracy. Regarding some of the main control variables, we find that evaluations of how democracy was performing were consistently associated with whether or not someone was on the winning side of a recent election, and by a person's economic circumstances. Winners, and those doing well in the economy, had more positive evaluations of how democracy was performing.

In sum, we can be confident that results are consistent with our primary hypothesis about social conditions driving evaluations of democratic processes. This is so when we consider different measures of inequality, when the analysis is limited to the EU, and when a different measure of proportionality is used. Moreover, results are robust regardless of whether we represent evaluations of democracy with our measure of the gap between expectations and perceptions, or with perceptions modeled as a function of expectations. We conducted additional tests (available from the authors) that further establish these results are not likely to be due to an artifact of model specification or 
measurement. Two points about this are noteworthy. First, we included additional country-level measures of institutions (a measure for presidential systems, and a measure of assembly size) and found these unrelated to evaluations of democracy. Second, we reestimated our models with a measure of democratic experience (years as a democracy since World War II). Despite being well correlated with our measure of corruption, our primary substantive results are unaffected by the inclusion of age of democracy. Third, when we replicated the analysis with OLS regressions with standard errors clustered at the country level, our substantive results are unchanged.

\section{Discussion and Conclusions}

Elections and party systems are among the core mechanisms of democracy. Disappointment and dissatisfaction with the functioning of these democratic processes can be a threat to the stability and legitimacy of democratic political systems. There is ample room for debate about the extent to which different electoral rules or party system features might improve how people view the performance of democracy in their country. Whatever the trajectory of this debate, many political scientists - the present authors included - have been motivated by the potential that electoral reforms have for enhancing the performance of electoral democracy, if only at the margins. A number of studies examining relationships between elements of electoral systems and satisfaction with democracy suggest that certain electoral rules - those that produce multipartyism, proportionality, and candidate-centered voting - can possibly enhance satisfaction with how democracy is performing. This would suggest democratic legitimacy could be enhanced when a country adopted such reforms to its electoral institutions. 
The results in this study, however, point to the limits of electoral reforms. It is noteworthy that previously demonstrated relationships between satisfaction with democracy, and electoral system features, appear to be rather ethereal. One major contribution of this paper is that our results challenge the premise that key features of electoral systems have substantive effects on how people evaluate the performance of electoral democracy. It is important to note that this finding is not dependent on use of the satisfaction with democracy question. We tested for relationships between electoral system features on perceptions of the quality of elections, on perceptions of the quality of choices offered by parties, and on satisfaction with democracy, and find that any potential electoral system effects wash out when we account for corruption and inequality.

We proposed a reason for this. Evaluations of the performance of elections and democracy are likely to evoke considerations of procedural and distributional fairness. Corruption is the antithesis of procedural fairness and greater income inequality may trigger perceptions of political as well as economic inequality. The point is not to say that the method of casting votes in a country, or the number of parties, or the proportionality of a party system should have no bearing on the considerations people have about how their democracy is performing. Rather, we propose that the presence of corruption and inequality are simply more visible, more immediate, and more consequential to people when they are asked to evaluate democratic processes and performance. Our results are consistent with this logic. We suggest it is very important to future cross-national research for these broad social forces to be considered when modeling links between electoral rules, political attitudes, and behavior. 
Institutions do matter as a factor affecting perceptions of how well elections and democracy are functioning. But the potential effects of electoral rules appear fragile when compared to the forces of corruption and income inequality. This should serve as a reminder as to what much of the earlier 'institutions matter' literature was emphasizing, such as state capacity and state institutions that have some autonomy from private economic interests. These are features of a democratic political system that are closely related to the rule of law, something that is undermined where there is greater corruption. Where income inequality is great or growing, and where corruption challenges the rule of law, the proportionality of translating votes to seats, or the method of voting for candidates versus parties, may be too subtle to affect perceptions of how democracy is working.

The robust relationship between corruption and inequality on attitudes, even when the analysis is limited to EU countries, must be acknowledged. While corruption erodes satisfaction with democracy and depressed confidence in elections and parties, perceptions of corruption amplified by media also provide right-wing populist parties opportunities for anti-democratic mobilization (Mudde 2006). Income inequality, if concentrated among the 'losers' of globalization, may likewise provide mobilization opportunities for nationalist, anti-democratic, far-right parties (Kriesi et al 2012). Results in this study suggest that reforms that address political corruption, that build the capacity of state institutions (in the Weberian sense), and that mitigate income inequality could have far more consequences on how people view elections and democracy than reforms targeting electoral democracy. 
Figure 1: Evaluations of Democracy, European Social Survey 2012.

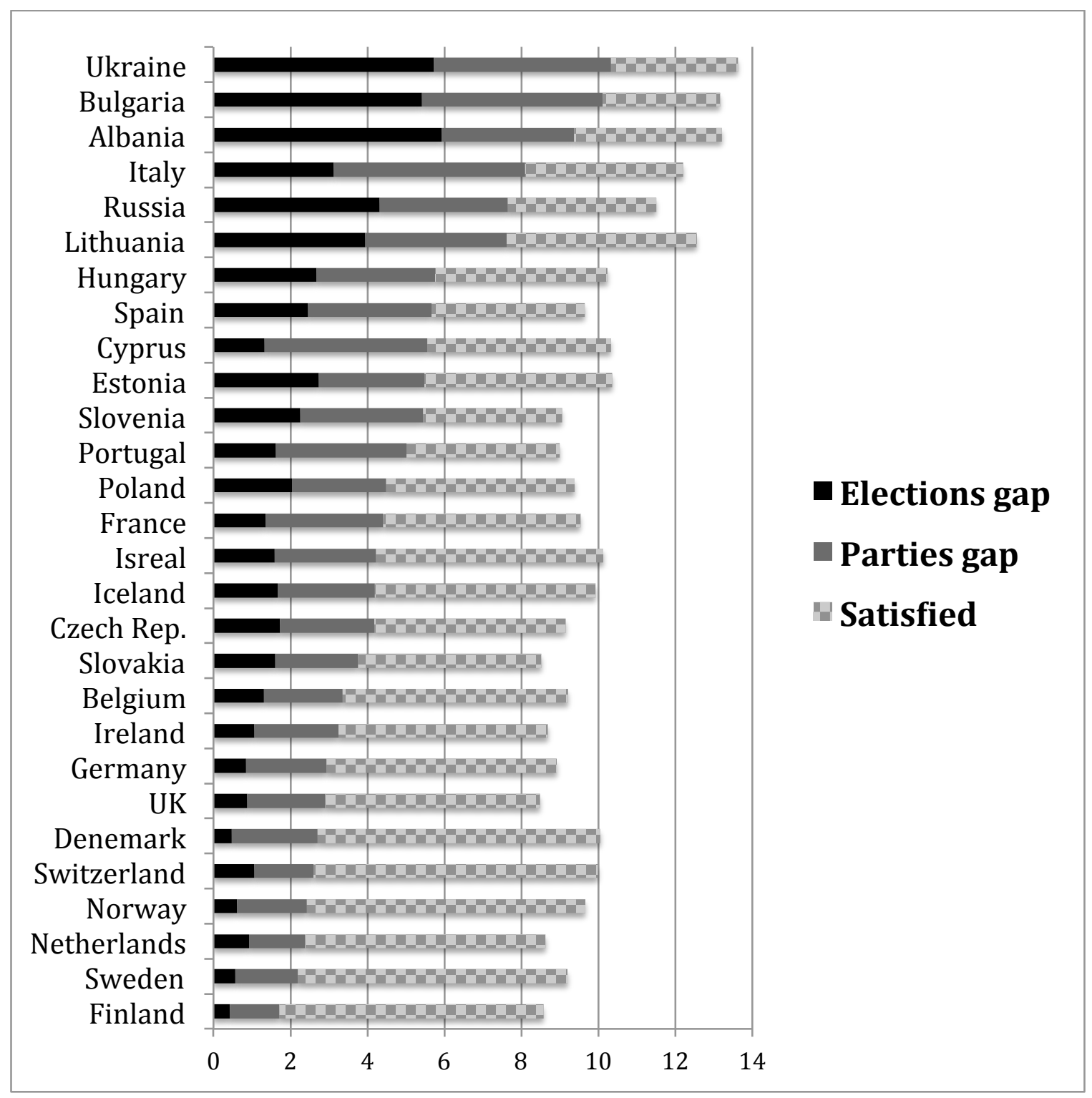

Source: ESS Wave 6, 2012-13.

Note: The first two values represent the difference between expectations about democracy and perceptions of its performance ( 0 - 10 scale, where higher = larger gap between expectations and perceptions). Third value, higher values reflect greater satisfaction with democracy (0-10 scale). See Appendix for item details.

* = EU nations where ESS 6 was conducted 
Table 1: Democratic expectations about elections being free and fair. (0-10 scale, high = larger gap between expectations and perceptions that elections are free and fair).

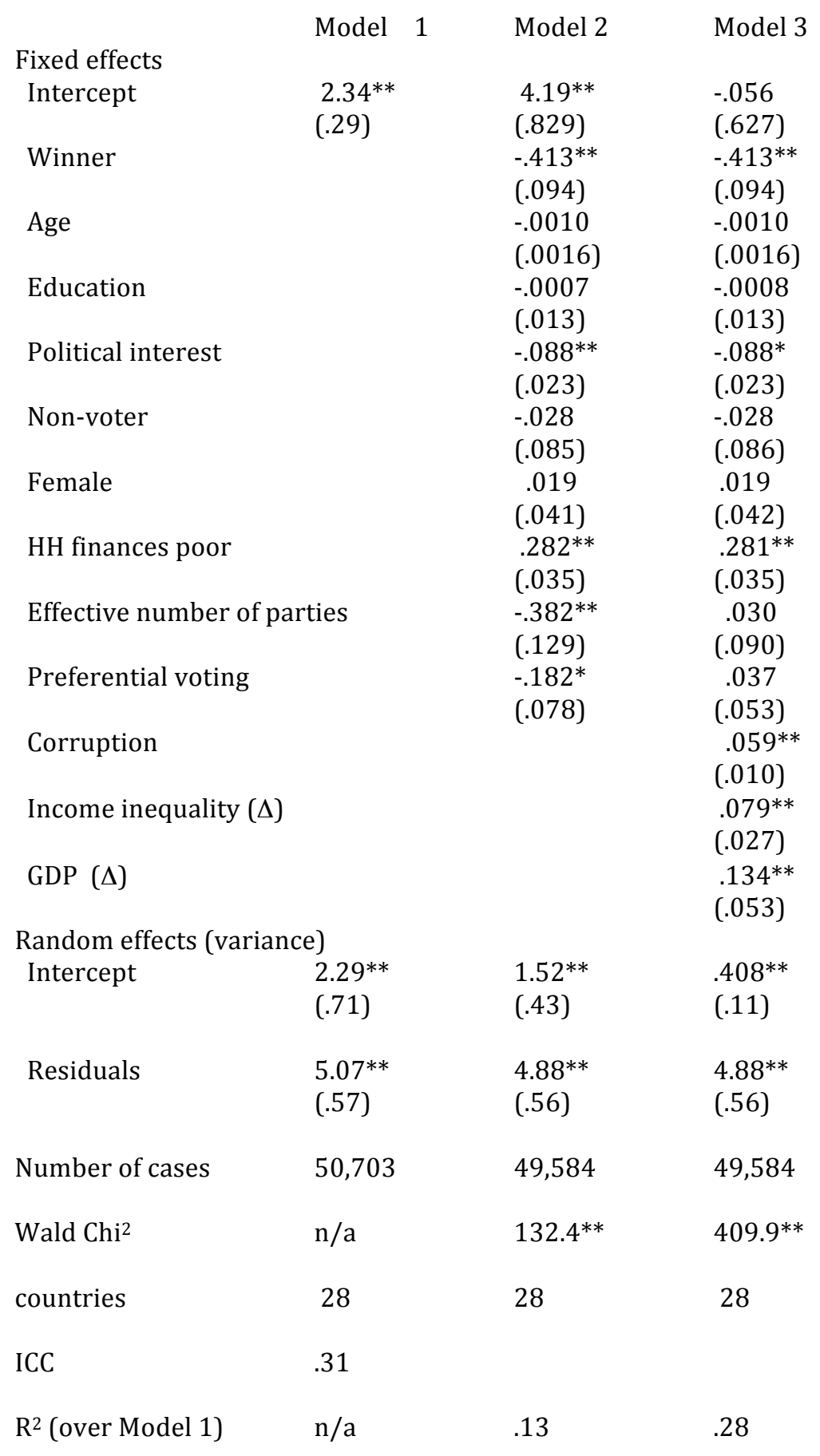

Source: European Social Survey 6.

Note: Multi-level models estimated with Stata 14 mixed, with weights. Standard errors in parentheses. $*^{* *}=$ p.$<.01$ (two-tail); ${ }^{*}=$ p. $<.05$ (two-tail). 
Table 2: Democratic expectations about parties presenting clear alternatives. $0-10$ scale, high = larger gap between expectations and perceptions that parties offer alternatives).

\begin{tabular}{|c|c|c|c|}
\hline \multirow{2}{*}{\multicolumn{4}{|c|}{ Fixed effects }} \\
\hline & & & \\
\hline Intercept & $\begin{array}{l}3.09^{* *} \\
(.175)\end{array}$ & $\begin{array}{l}3.71^{* *} \\
(.402)\end{array}$ & $\begin{array}{l}1.35^{* *} \\
(.400)\end{array}$ \\
\hline Winner & & $\begin{array}{l}-.226^{* *} \\
(.055)\end{array}$ & $\begin{array}{l}-.227^{* *} \\
(.055)\end{array}$ \\
\hline Age & & $\begin{array}{c}.0014 \\
(.0013)\end{array}$ & $\begin{array}{l}.0014 \\
(.0013)\end{array}$ \\
\hline Education & & $\begin{array}{l}.109 * * \\
(.013)\end{array}$ & $\begin{array}{l}.108^{* *} \\
(.012)\end{array}$ \\
\hline \multicolumn{2}{|l|}{ Political interest } & $\begin{array}{l}.076^{* *} \\
(.025)\end{array}$ & $\begin{array}{l}.076^{* *} \\
(.026)\end{array}$ \\
\hline \multicolumn{2}{|l|}{ Non-voter } & $\begin{array}{l}-.066 \\
(.057)\end{array}$ & $\begin{array}{l}-.066 \\
(.057)\end{array}$ \\
\hline \multicolumn{2}{|l|}{ Female } & $\begin{array}{l}-.033 \\
(.033)\end{array}$ & $\begin{array}{l}-.033 \\
(.033)\end{array}$ \\
\hline \multicolumn{2}{|l|}{ HH finances poor } & $\begin{array}{l}.186^{* *} \\
(.033)\end{array}$ & $\begin{array}{l}.185^{* *} \\
(.033)\end{array}$ \\
\hline \multicolumn{2}{|c|}{ Effective number of parties } & $\begin{array}{l}-.293^{* *} \\
(.067)\end{array}$ & $\begin{array}{l}-.070 \\
(.054)\end{array}$ \\
\hline \multicolumn{2}{|l|}{ Preferential voting } & $\begin{array}{l}-.113^{* *} \\
(.045)\end{array}$ & $\begin{array}{l}.025 \\
(.030)\end{array}$ \\
\hline \multicolumn{2}{|l|}{ Corruption } & & $\begin{array}{l}.027^{* *} \\
(.006)\end{array}$ \\
\hline \multicolumn{2}{|c|}{ Income inequality $(\Delta)$} & & $\begin{array}{l}.063^{* *} \\
(.016)\end{array}$ \\
\hline \multicolumn{2}{|l|}{$\operatorname{GDP}(\Delta)$} & & $\begin{array}{l}-.115^{*} \\
(.054)\end{array}$ \\
\hline \multicolumn{4}{|c|}{ Random effects (variance) } \\
\hline Intercept & $\begin{array}{c}.83^{*} \\
(.19)\end{array}$ & $\begin{array}{l}.51^{* *} \\
(.12)\end{array}$ & $\begin{array}{l}.20^{*} \\
(.05)\end{array}$ \\
\hline Residuals & $\begin{array}{l}6.12^{* *} \\
(.36)\end{array}$ & $\begin{array}{l}6.05^{* *} \\
(.35)\end{array}$ & $\begin{array}{l}6.05^{* *} \\
(.35)\end{array}$ \\
\hline Number of cases & 49,246 & 48,193 & 48,193 \\
\hline Wald $\mathrm{Chi}^{2}$ & $\mathrm{n} / \mathrm{a}$ & $167.9^{* *}$ & $401.0^{* *}$ \\
\hline countries & 28 & 28 & 28 \\
\hline ICC & .12 & & \\
\hline $\mathrm{R}^{2}$ (over Model 1) & $\mathrm{n} / \mathrm{a}$ & .06 & .10 \\
\hline
\end{tabular}

Source: European Social Survey 6.

Note: Multi-level models estimated with Stata 14 mixed, with weights. Standard errors in parentheses. ${ }^{* *}=$ p.$<.01$ (two-tail); ${ }^{*}=$ p. $<.05$ (two-tail); 
Table 3: Satisfaction with democracy $(0-10$, high = very satisfied).

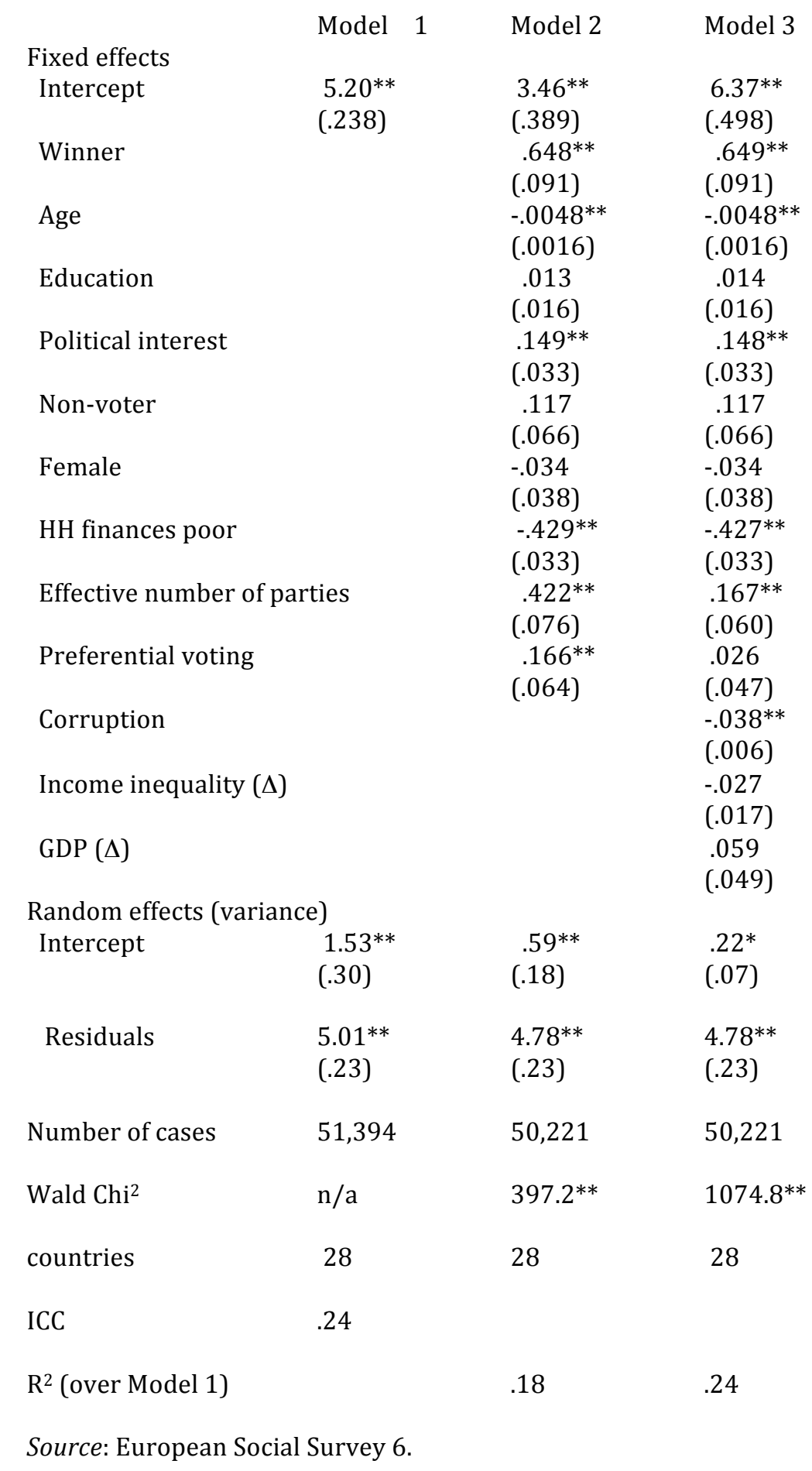

Note: Multi-level models estimated with Stata 14 mixed, with weights. Standard errors in parentheses. $*^{* *}=$ p. $<.01$ (two-tail); ${ }^{*}=$ p. $<.05$ (two-tail). 


\section{References}

Anderson, C. \& Guillory, C. (1997). Political institutions and satisfaction with democracy. American Political Science Review 91(1): 66-81.

Anderson, C. \& Tverdova, Y. (2003). Corruption, political allegiances, and attitudes toward government in contemporary democracies. American Journal of Political Science 47(1): 91-109.

Anderson, C., Blais, A., Bowler, S., Donovan, T. \& Listhaug, O. (2005). Losers' consent: Elections and democratic legitimacy. Oxford: Oxford University Press.

Aarts, K. \& Thomassen, J. (2008). Satisfaction with democracy: Do institutions matter? Electoral Studies 27: 5-18.

Bartles, L. (2009) Unequal democracy: The political economy of the new gilded age. Princeton University Press.

Carey, J. \& Shugart, M. (1995). Incentives to cultivate a personal vote: A rank ordering of electoral formulas. Electoral Studies 14: 417-439.

Canache, D., Mondak, D. \& Seligson, M. (2001). Meaning and measurement in crossnational research on satisfaction with democracy. Public Opinion Quarterly 65: 506-28.

Clarke, H. \& Kornberg, A. 1992. Support for the Canadian federal Progressive Conservative party since 1988. Canadian Journal of Political Science 25: 29-53.

Clausen, B., Kray, A. \& Nyiri, Z. (2011). Corruption and confidence in public institutions: Evidence from a global survey. World Bank Economic Review 25: 212249.

Dahl, R. (1956). A preface to democratic theory. Chicago: University of Chicago Press.

Dalton, R. 2005. The social transformation of trust in government. International Review of Sociology 15(1): 133-154.

Dalton, R. (2007). Partisan mobilization, cognitive mobilization, and the changing of the American electorate. Electoral Studies 26: 274-86.

Dalton, R. (1999). Political support in advanced industrial democracies. In P. Norris (ed.) Critical Citizens: Global Support for Democratic Government. Oxford: Oxford University Press. 
Dotti S., Giulia, M. \& Magistro, B. (2016). Increasingly unequal? The economic crisis, social inequalities and trust in the European Parliament in 20 European countries. European Journal of Political Research 55(2): 246-264.

Easton, D. 1965. A systems analysis of political life. New York: John Wiley.

Farrell, D. \& McAllister, I. (2006). Voter satisfaction and electoral systems: Does preferential voting in candidate systems make a difference? European Journal of Political Research 45(5): 723-749.

Ferrin, M. (2016). An empirical assessment of satisfaction with democracy. In Ferrin, M. \& Kriesi, H. (eds.) How europeans view and evaluate democracy. Oxford University Press.

Fuchs, D. (1999). The democratic culture of unified Germany. In Norris, P. (ed.) Critical citizens: Global support for democratic government. Oxford: Oxford University Press.

Fuchs, D. \& Klingemann, H. D. (1995). Citizens and the state. Oxford University Press.

Gallagher, M. (2014). Election indices dataset at http://www.tcd.ie/Political_Science/staff/michael_gallagher/EIsystems/index.php

Gallagher, M. \& Mitchel, P. (2008). The politics of electoral systems. Oxford University Press.

Gallagher, M. (1991). Proportionality, disproportionality, and electoral system. Electoral Studies 10(1): 33-51.

Harmel, R. \& Robertson, J. (1986). Government stability and regime support. Journal of Politics 48(4): 1029-40

Hibbing, J. \& Theiss-Morse. E. (2001). Process preferences and american politics: what the people want government to be. American Political Science Review 95(1): 145-53.

Horowitz, D. (1991). A democratic South Africa? constitutional engineering in a divided society. Berkeley: University of California Press.

Karp, J. \& Banducci, S. (2008). Political efficacy and participation in twenty-seven democracies: How electoral systems shape political behavior. British Journal of Political Science 38(2): 311-334.

Karp, J., Banducci, S. \& Bowler, S. (2003). To know it is to love it: Satisfaction with democracy in the European Union. Comparative Political Studies 36(3): 271-292. 
Kasse, M. (1988). Political alienation and protest In (M. Dogan ed) Comparing pluralist democracies: Strains in legitimacy. Boulder, CO: Westview Press.

Klingemann, H. D. (1999). Mapping political support in the 1990s: A global analysis. In P. Norris (ed.) Critical citizens: Global support for democratic government. Oxford: Oxford University Press.

Kuechler, M. (1991). The dynamics of mass support in Western Europe: Methodological problems and preliminary findings. Eurobarometer.

Kriesi, H., et al. (2012). Political conflict in Western Europe. Cambridge: Cambridge University Press.

Leiter, D. \& Clark, M. (2015). Valence and satisfaction with democracy: A cross-national analysis of nine Western European democracies. European Journal of Political Research 54(3): 543-562.

Lijphart, A. (1994). Electoral systems and party systems: A study of twenty-seven democracies: 1945-1990. Oxford University Press.

Lijphart, A. (1999). Patterns of democracy: government forms and performance in thirty-six countries. New Haven: Yale University Press.

Lijphart, A. \& Grofman, B. (1984). Choosing an electoral system: Issues and alternatives. New York: Praeger.

Linde, J. \& Ekman, J. (2003). Satisfaction with democracy: A note on a frequently used indicator in comparative politics. European Journal of Political Research 42(3): $391-408$.

Lipset, S. (1960). Political man: The social basis of politics. Doubleday \& Company.

Lockerbie, B. (1993). Economic dissatisfaction and political alienation in Western Europe. European Journal of Political Research 23: 281-293.

Mudde, C. (2006). The populist zeitgeist. Government and Opposition 39(4): 542-563.

Norris, P. (2014). Why electoral integrity matters. New York: Cambridge University Press.

Norris, P. (2004). Electoral engineering: Voting rules and political behavior. Cambridge University Press.

Norris, P. (1999). Critical citizens: Global support for democratic government. Oxford: Oxford University Press. 
Pharr, S. \& Putnam, R. (2000). Disaffected democracies: What's troubling the trilateral democracies? Princeton: Princeton University Press.

Powell, G. B. (1982). Contemporary democracies: Participation, stability, and violence. Harvard University Press.

Powell, G. B. (2000). Elections as instruments of democracy: Majoritarian and proportional visions. New Haven, Yale University Press.

Reilly, B. (2001). Democracy in divided societies: Electoral engineering for conflict management. Cambridge: Cambridge University Press.

Reynolds, A. (2002). The architecture of democracy: Constitutional design, conflict management, and democracy. Oxford University Press.

Rose-Ackerman, S. (1978). Corruption: A study in political economy. New York: Academic Books.

Rose R. \& Mishler, W. (2002). Comparing regime support in non-democratic and democratic countries. Democratization 9(2): 1-20.

Seyd, B. (2015). Exploring political disappointment. Parliamentary Affairs doi: $10.1093 / \mathrm{pa} / \mathrm{gsv} 018$

Shugart, M. (2001). Electoral 'efficiency' and the move to mixed member systems. Electoral Studies 20: 173-193.

Singh, S. (2013). Not all election winners are equal: Satisfaction with democracy and the nature of the vote. European Journal of Political Research 53(2): 308-327.

Singh, S, Karakoc. E. \& Blais, A. (2012). Differentiating winners: How elections affect satisfaction with democracy. Electoral Studies 31(1): 201-11.

Solt, F. (2008). Economic inequality and democratic political engagement. American Journal of Political Science 52(1): 48-60.

Steenbergen, M. \& Jones. B. (2002). Modeling multilevel data structures. American Journal of Political Science 46(1): 218-327.

Thomassen, J. \& van der Kolk, H. (2009). effectiveness and political support in old and new democracies. In Klingemann, H.D. (ed.) The comparative study of electoral systems. Oxford University Press.

Triesman, D. (2000). The causes of corruption: A Cross-national study. Journal of Public Economics 76(3): 399-457. 
Tyler, T. (1990). Why people obey the law: Procedural justice, legitimacy, and compliance. New Haven: Yale University Press.

Sartori, G. (1997). Comparative constitutional engineering: An inquiry into structures, incentives and outcomes. New York: NYU Press.

Wagner, A., Schneider, F. \& Hall, M. (2009). The quality of institutions and satisfaction with democracy in Western Europe - A panel analysis. European Journal of Political Economy 25: 30-41.

Weatherford, M. S. (1992). Measuring political legitimacy. American Political Science Review 86(1): 149-166.

Weil, F. (1989). The sources and structure of legitimation in western democracies: A consolidated test with time series data in six countries since World War II American Sociological Review 54: 682.706. 